\title{
DNA Analysis Confirms Macroptilium lathyroides as Alternative Host of Bean golden yellow mosaic virus
}

\author{
V. Bracero and L. I. Rivera, Department of Crop Protection, and J. S. Beaver, Department of Agronomy and Soils, \\ University of Puerto Rico-Mayagüez Campus, Mayagüez, Puerto Rico 00681-9030
}

\begin{abstract}
Bracero, V., Rivera, L. I., and Beaver, J. S. 2003. DNA analysis confirms Macroptilium lathyroides as alternative host of Bean golden yellow mosaic virus. Plant Dis. 87:1022-1025.

The leguminous weed Macroptilium lathyroides is considered a potential host of the Bean golden yellow mosaic virus (BGYMV; BGMV = Mesoamerican isolates). To determine if $M$. lathyroides could be a host for BGYMV, an infectivity cycle was established between this weed and Phaseolus vulgaris. Virus transmission was carried out using the whitefly, Bemisia argentifolli, as a vector. Inoculated plants of both species were examined for symptoms such as mosaic, stunting, and leaf distortion. P. vulgaris and M. lathyroides showed golden yellow mosaic symptoms during all infectivity cycle stages. Symptomatic plants of both species were tested for BGYMV using polymerase chain reaction (PCR) and nucleotide sequence analysis. Two degenerate primers sets were used for PCR to detect viral DNA: PAL1v1978/PAR1c715 and PCRc2/PBL12039. PCR analysis using primers PCRc2/PBL12039 amplified viral DNA for component B from both plant species. Nucleotide sequence analysis revealed a $93 \%$ identity between the virus isolated from M. lathyroides and the Puerto Rican isolate of BGYMV. These results confirmed that $M$. lathyroides could serve as an alternative host of BGYMV and that an infectivity cycle of BGYMV could possibly occur between $P$. vulgaris and M. lathyroides in Puerto Rico.
\end{abstract}

Additional keywords: DNA nucleotide sequence analysis, fabaceae, geminivirus

Bean golden yellow mosaic virus (BGYMV; BGMV = Mesoamerican isolates) is the most important disease of Phaseolus vulgaris (L.) in Central America and the Caribbean (11,12). Geminiviruses (genus: Begomovirus) like BGYMV cause devastating crop diseases throughout the tropics and are transmitted by whiteflies of the genus Bemisia (Homoptera: Aleyrodidae) $(9,11)$. Disease symptoms include intense yellowing, mosaic, stunting, and distortion of leaves and pods. The term "golden-yellow mosaic", recently adopted by Fauquet (6), was first used by Bird (2) to describe these symptoms in lima beans (Phaseolus lunatus) and common beans.

The role of weeds as reservoirs for BGYMV has been subject to speculation and debate for many years. In 1971,

Corresponding author: V. Bracero

E-mail: vilmaris_bracero@cca.uprm.edu

This research was sponsored by USDA TSTAR grant Z90-C in collaboration with the Department of Plant Pathology, University of Florida; and the Department of Crop Protection, College of Agricultural Sciences of the University of Puerto Rico-Mayagüez Campus.

Accepted for publication 23 April 2003.

Publication no. D-2003-0710-01R

(C) 2003 The American Phytopathological Society
Gamez (7) observed symptoms in hundreds of bean cultivars and other legumes inoculated with the virus, and suggested that legume weeds might serve as reservoirs of the geminivirus. In 1981, Chagas et al. $(3,4)$ discussed the possibility of various weeds serving as alternative hosts (e.g., a Canavalia sp., Crotalaria spp., Macroptilium lathyroides, and $M$. erythroloma). In 1987, Haber et al. (8), using fingerprint diagnosis, confirmed the presence of distinct sets of restriction fragments that specifically hybridized with BGMV DNA sequences in M. lathyroides and Malvastrum coromandelianum. None of these early studies, however, established infectivity cycles as proof to corroborate their findings.

Roye et al. (15) characterized geminiviruses infecting Macroptilium lathyroides using polymerase chain reaction (PCR), DNA hybridization, and nucleotide sequence analysis. Their results indicate that both crop- and weed-infecting geminiviruses are related, but different, and redefined the geminivirus cluster infecting $M$. lathyroides in Jamaica as new. Idris et al. (10) reported a new geminivirus from $M$. lathyroides, distinct from BGYMV, that caused green-yellow foliar symptoms and stunting, reminiscent of symptoms caused by BGYMV-PR in beans. The authors named the virus Macroptilium mosaic virus
(MaMV). More recently, Ramos and Fernandez (13) compared the DNA-A sequence of $M$. lathyroides field samples showing bright yellow mosaic symptoms with various strains of geminiviruses, including BGYMV, Tomato leaf curl virus, and Sida golden mosaic virus. Data revealed a new begomovirus; therefore, they proposed the name Macroptilium yellow mosaic virus (MaYMV) for a new virus.

$M$. lathyroides, or scarlet bean, a common leguminous weed, has been considered to be a potential reservoir for BGYMV. Given the abundance of this weed in and around bean fields, it is important to determine if $M$. lathyroides could be an alternative host for BGYMV in order to develop better management and control strategies under field conditions. To date, no studies have been conducted using an infectivity cycle to determine whether or not this weed is a potential reservoir of BGYMV in Puerto Rico.

\section{MATERIALS AND METHODS}

Plant material. M. lathyroides seed were scarified by cutting one end of each seed. M. lathyroides and $P$. vulgaris seed were germinated in a moist chamber and planted in Pro-mix using 15-cm-diameter pots ( 3 seed per pot) and grown in the greenhouse at $27^{\circ} \mathrm{C}$ and $75 \%$ relative humidity.

Virus transmission by whiteflies. Aviruliferous whiteflies were collected from Glycine max L. Merr. plants growing in a greenhouse at the University of Puerto Rico-Mayagüez Campus. The primary viral source was taken from the BGYMVsusceptible $P$. vulgaris cv. Top Crop growing and infected once in a greenhouse. Healthy bean plants were maintained in a separate greenhouse. Twelve days after planting, 45 bean seedlings of susceptible cvs. Top Crop or Mayflower were inoculated once with 10 viruliferous whiteflies per plant for $48 \mathrm{~h}$. The whiteflies had fed from bean plants infected with BGYMV, as suggested by Adamés-Mora (1).

Infectivity cycle between $P$. vulgaris and $M$. lathyroides. Twelve-day-old $P$. vulgaris plants were infected once with viruliferous whiteflies under greenhouse conditions. After $P$. vulgaris plants showed symptoms, we allowed virus-free whiteflies to feed on the $P$. vulgaris plants. 
These viruliferous whiteflies were used to transmit the virus from infected bean plants to healthy, 12-day-old $M$. lathyroides plants. After infection, M. lathyroides plants were used as a source of inoculum to infect healthy $P$. vulgaris plants, to complete the infectivity cycle between the two plant species. A first set of experiments was conducted with bean $\mathrm{cv}$. Top Crop and a second set using bean cv. Mayflower. Each plant species was inoculated once with viruliferous whiteflies. Negative control consisted of 15 plants of each species inoculated with 10 aviruliferous whiteflies per plant.

PCR. Young leaf tissue samples were collected 15 days after inoculation from $P$. vulgaris and $M$. lathyroides plants for DNA extraction, using the minipreparation method described by Dellaporta (5). Degenerate primers designed by Rojas et al. (14) were obtained from the University of Wisconsin-Madison (14). The PCR reaction consisted of $2.5 \mu \mathrm{l}$ of sample DNA solution $(200 \mathrm{ng} / \mathrm{ml}), 2.5 \mu \mathrm{l}$ of dNTPs (1 $\mu \mathrm{M}), 2.5 \mu \mathrm{l}$ of $\mathrm{Mg}^{2+}(25 \mathrm{mM}), 2.5 \mu \mathrm{l}$ of $\mathrm{Mg}$ buffer (10x) for a total volume of $25 \mu \mathrm{l}, 0.5$ $\mu \mathrm{l}$ of each primer $(0.02 \mu \mathrm{M})$, and $0.1 \mu \mathrm{l}$ of Taq polymerase (Promega Corp., Madison, WI) in a total volume of $25 \mu \mathrm{l}$. Each reaction mixture was covered with 25 to 50 $\mu \mathrm{l}$ of mineral oil to prevent evaporation during the amplification. Viral DNA was amplified using a thermocycler (Gene Amp System 2400; Perkin Elmer Co., Norwalk, $\mathrm{CT})$ by 30 cycles of denaturation, annealing, and extension conditions of 1 $\min$ at $94^{\circ} \mathrm{C}, 2 \mathrm{~min}$ at $55^{\circ} \mathrm{C}$, and $2 \mathrm{~min}$ at $72^{\circ} \mathrm{C}$, respectively. Amplified DNA was electrophoresed in $0.8 \%$ agarose gel for 5 to $7 \mathrm{~min}$ at 110 volts, in TBE buffer (45
mM Tris-borate, 1 mM EDTA, pH 8). Gels were viewed with ultraviolet light after staining in $7 \%$ ethidium bromide.

DNA cloning and sequencing. The amplified DNA band was excised from a gel previously stained with ethidium bromide and recovered with a glass matrix (Gene Clean; Bio 101, La Jolla, CA). The 600-bp DNA fragment was inserted into plasmid pGEM-T Easy Vector (Promega Corp.). The DNA was cut with the endonuclease EcoRI. PCR-amplified DNA with insert was extracted twice with an equal volume of phenol:chloroform:isoamyl alcohol (25:24:1; PCI method), then used to transform Escherichia coli strain XL1-Blue. Bacterial colonies with recombinant plasmids ( $\beta$-galactosidase negative) were selected for further characterization. DNA sequences were determined by the dideoxynucleotide chain termination method. DNA sequences were analyzed with the software of the Genetics Computer Group, University of Wisconsin-Madison and BLAST Database.

\section{RESULTS}

Viral transmission through whiteflies. Whiteflies effectively transmitted BGYMV between $P$. vulgaris and $M$. lathyroides through an infectivity cycle established at a greenhouse at the University of Puerto Rico-Mayagüez Campus; $100 \%$ plants were infected. We observed that $B$. argentifolli preferred young plant tissues and were attracted to both plant species. Viral transmission through its vector is an effective and natural way to spread BGYMV in the field.

Symptoms of BGYMV. P. vulgaris cvs. Top Crop and Mayflower showed typical golden mosaic symptoms on the leaves, whereas $M$. lathyroides showed similar symptoms around leaf veins, 12 to 15 days after inoculation (Fig. 1). Stunting was observed on neither $P$. vulgaris nor $M$. lathyroides plants, although leaf distortion was observed in both species.

PCR. Primers set to detect viral DNA for component A (PCRc2/PBL12039) and viral DNA for component B (PAL1v1978/ PAR1c715) were used successfully before by Rojas et al. (14) to amplify geminiviruses. In our studies, electrophoresis of amplified DNA extracted from infected $M$. lathyroides plants showed intense and clear 600-bp bands, using primers for viral DNA component B (Fig. 2). We chose these products for further PCR experiments because they contained a highly variable region. The DNA product was successfully cloned in an E. coli plasmid for further analysis.

Cloning and sequencing. After cloning the viral DNA from $M$. lathyroides plants, we extracted the plasmid pGEM-T Easy Vector and cut it with EcoRI, then confirmed viral DNA insertion using electrophoretic techniques (Fig. 3). Two clones were obtained: pII1 and pII3, with a DNA concentration of 347 and $298 \mathrm{ng} / \mathrm{ml}$, respectively. Both DNA clones were further used for DNA nucleotide sequence analysis.

Nucleotide sequence analysis. The viral DNA-B clones obtained from M. lathyroides were compared among them and also with sequences available for other geminiviruses using BLAST program and Bio Comp databases. The viral DNA from M. lathyroides shared 93, 94, 95, and 96\% nucleotide sequence identity with BGYMV

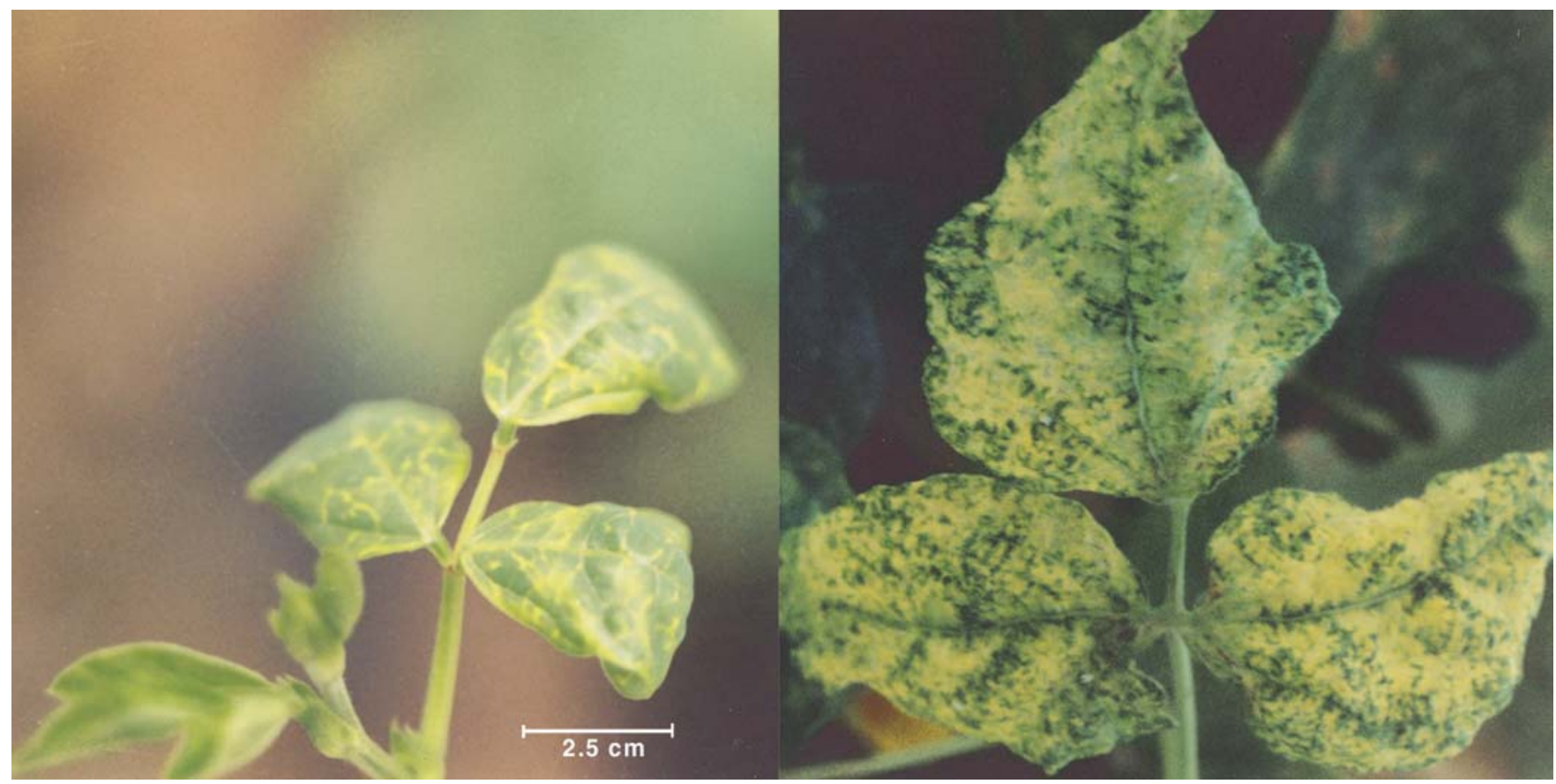

Fig. 1. Golden yellowing mosaic symptoms and leaf distortion observed on leaves of Macroptilium lathyroides and Phaseolus vulgaris plants, 15 days after inoculation with Bean golden yellow mosaic virus during an infectivity cycle established under greenhouse conditions. 


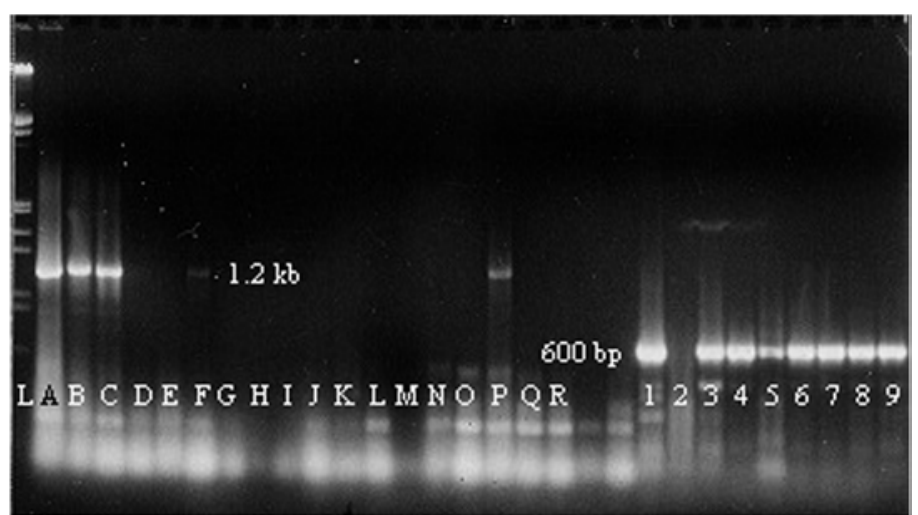

Fig. 2. Agarose gel electrophoresis of polymerase chain reaction products from DNA of Bean golden yellow mosaic virus (BGYMV) obtained from Macroptilium lathyroides tissues. Two sets of primers were used to detect component A or B of BGYMV. Ladder size marker $=1.0$ $\mathrm{kb}$ (lane L); M. lathyroides infected with BGYMV was detected with primers for component A (lanes A-H); M. lathyroides infected with BGYMV was detected with primers for component B (lanes 1-9). isolates from the Dominican Republic, Guatemala, Puerto Rico, and Puerto RicoJapan (GenBank accession numbers L01636, M91605, M10080, and D00200), respectively. In spite of the high variability of the amplified noncoding protein region of the DNA-B, sequence analysis showed a high percentage of nucleotide sequence identity of the DNA virus found in $M$. lathyroides with BGYMV.

Confirmation of BGYMV infectivity cycle. To confirm that whiteflies had transmitted BGYMV from $M$. lathyroides to $P$. vulgaris, we amplified the DNA extracted from whitefly-infested $P$. vulgaris cv. Mayflower using primers for component B, to detect BGYMV. The 600-bp band obtained from $P$. vulgaris tissues was consistent with the band observed before for BGYMV from $M$. lathyroides. These products were consistent with PCR products obtained by Rojas (14).

\section{DISCUSSION}

Based on our results, we conclude that BGYMV infected both bean and the common legume weed M. lathyroides. Symptom expression in $M$. lathyroides was a golden yellow mosaic near the leaf veins. Nucleotide sequence analysis showed a 93\% identity with BGYMV. Our findings, using DNA nucleotide sequence analysis, indicate that there is little divergence in the viral nucleotide sequence present in $P$. vulgaris and $M$. lathyroides tissues. These findings differ from Roye et al., who report phylogenetic differences among several weed viruses, including a golden mosaic virus from $M$. lathyroides, using DNA sequencing $(15,16)$. The authors established that the geminiviruses infecting weeds in Jamaica are different from those infecting important crops even though the authors do not specify whether or not $M$. lathyroides was exposed to BGYMV. Roye et al. $(15,16)$ described a partial coat protein gene sequence for Macroptilium spp.-infecting geminiviruses from Puerto Rico and that this virus was different from Macroptilium spp.-infecting viruses found in Jamaica. They concluded that the majority of the viruses characterized from Jamaica were new viruses that had not been reported previously.

In addition, PCR amplification of viral DNA-B confirmed that the virus infecting both plant species was bipartite, such as BGYMV. The amplified region of component $\mathrm{B}$ is considered of high variability because there is no gene coding for proteins in this region. This high variability region among DNA-B of different geminiviruses allows a more specific search when characterizing the virus. We obtained a 600-bp fragment for DNA-B, which is consistent with BGYMV. Fragment sizes can be different among geminiviruses; therefore, this fact is useful for viral characterization (14).

Fig. 3. DNA nucleotide sequence analysis: Comparison between clone pII1 and Bean golden mosai virus-Puerto Rico (BGMV-PR). Complementary nucleotides between clone pII1 and BGMV-PR were paired by a dash. These two clones shared a $93 \%$ similarity. 
In our study, we provide evidence that M. lathyroides might be a reservoir of BGYMV under field conditions in Puerto Rico. Management of $M$. lathyroides growing in and around bean fields could be a useful strategy to avoid the spread of BGYMV. Further research on interactions with BGYMV and other weed geminiviruses with $P$. vulgaris is recommended.

\section{ACKNOWLEDGMENTS}

We thank D. Maxwell at the Department of Plant Pathology, University of Wisconsin-Madison for his advice and technical support, and all reviewers of the manuscript for their time and effort.

\section{LITERATURE CITED}

1. Adamés-Mora, C., Beaver, J., and Díaz, O. 1996. Una metodología para evaluar en el invernadero el virus del mosaico dorado de la habichuela. J. Agric. Univ. P. R. 80:65-72.

2. Bird, J., Pérez, J. E., Halconero, R., Vakili, N. G., and Meléndez, P. L. 1972. A whiteflytransmitted golden-yellow mosaic of Phaseolus lunatus in Puerto Rico. J. Agric. Univ. P. R. 56:64-74.

3. Chagas, C. M., Barradas, M., and Vicente, M.. 1981. Macroptilium erythroloma (Mart. ex Benth.) Urb.- Leguminosae- Possivel reser- vatorio do virus do mosaico dourado do feijoeiro (VMDF). Arq. Inst. Biol. Sao Paulo 48:113-116.

4. Chagas, C. M., Barradas, M., and Vicente, M. 1981. Espécies hospedeiras do vírus do mosaico dourado do feijoeiro. Arq. Inst. Biol. São Paulo 48:123-127. Artigo 23.

5. Dellaporta, S. L., Wood, J., and Hicks, J. B. 1983. A plant DNA minipreparation: Version II. Plant Mol. Biol. Rep. 1:19-21.

6. Fauquet, C. M., Maxwell, D. P., Grononborn, B., and Stanley, J. 2000. Revised proposal for naming geminiviruses. Arch. Virol. 145:17431761.

7. Gámez, R. 1971. Los virus del frijol en Centroamérica. Transmisión por moscas blancas (Bemisia tabaci Gen.) y plantas hospedantes del virus del mosaico dorado. Turrialba 21:22-27.

8. Haber, S., Polston, J. E., and Bird, J. 1987. Use of DNA to diagnose plant diseases caused by single-strand DNA plant viruses. Can. Plant Pathol. 9:156-161.

9. Harrison, B. 1981. Plant virus ecology: ingredients, interactions and environmental influences. Ann. Appl. Biol. 99:192-209.

10. Idris, A. M., Bird, J., and Brown, J. K. 1999. First report of bean-infecting begomovirus from $M$. lathyroides in Puerto Rico that is distinct from Bean Golden Mosaic Virus. Plant Dis. 83:1071.
11. Markham, P. G., Bedford, I. D., Liu, S., and Pinner, M. S. 1994. The transmission of geminiviruses by Bemisia tabaci. Pestic. Sci. 42:123-128.

12. Morales, F. J. 1998. The emergence of whitefly-transmitted geminiviruses as important pathogens of cultivated plants in Latin America. (Abstr.) In: Second International Workshop on Bemisia and Geminiviruses. San Juan, Puerto Rico.

13. Ramos, P. L., and Fernández, A. 2002. Macroptilium yellow mosaic virus, a new begomovirus infecting Macroptilium lathyroides in Cuba. Plant Dis. 86:1049.

14. Rojas, M. R., Gilbertson, R. L., Russell, D. R., and Maxwell, D. P. 1993. Use of degenerated primers in the polymerase chain reaction to detect whitefly- transmitted geminiviruses. Plant Dis. 77:340-347.

15. Roye, M. E., McLaughlin, W. A., Nakhla, M. K., and Maxwell, D. P. 1997. Genetic diversity among geminiviruses associated with the weeds species Sida spp., Macroptilium lathyroides and Wissadula amplissima from Jamaica. Plant Dis. 81:1251-1258

16. Roye, M. E., McLaughlin, W. A., and Spence, J. D. 1999. The common weed Macroptilium lathyroides is not a source of crop-infecting geminiviruses from Jamaica. Trop. Agric. 76:256-262. 